\title{
INSTRUCTOR SATISFACTION AND Motivation in Online Teaching Environments: A Job Design Framework
}

Barry A. Friedman, Sarah Bonzo, and Gregory F. Ketcham

Barry A. Friedman (barry.friedman@oswego.edu) is a Professor of Human Resource Management and Organizational Behavior at the School of Business, State University of New York at Oswego, 247 Rich Hall, 7060 Route 104, Oswego, New York 13126-3599.

Sarah Bonzo (sarah.bonzo@oswego.edu) is an Assistant Professor of Health Services Administration and Operations at the School of Business, State University of New York at Oswego, 250 Rich Hall, 7060 Route 104, Oswego, New York 13126-3599.

Gregory F. Ketcham (gregory.ketcham@oswego.edu) is Director, Academic Programs and Distance Learning Department of Extended Learning, State University of New York at Oswego, Marano Campus Center 151J Oswego, NY 13126.

Correspondence concerning this paper should be addressed to Barry A. Friedman. 


\title{
42 The BRC Academy Journal of Education Vol. 6, No. 1
}

\begin{abstract}
Research that compares online and traditional classroom instruction is plentiful but focuses mostly on student satisfaction and learning outcomes. Despite advancements in online learning management systems, proliferation of personal devices adapted for online learning, increasing demand for flexible degree programs, and institutional pressure to offer more online courses, many instructors resist the transition to teaching online. Research that addresses instructors' satisfaction and motivation to teach online is therefore important. Few models link satisfaction to the work characteristics or provide suggestions for improvement. We propose that the nature of the work itself influences instructor satisfaction and motivation to teach online. We therefore evaluate online instructor satisfaction and motivation using the well-accepted core characteristics job design model (Hackman, Oldham, Janson, \& Purdy, 1975), and offer job design prescriptions that increase instructor satisfaction and motivation to teach online.
\end{abstract}

Keywords: online instruction, motivation, faculty satisfaction

DOI: http://dx.doi.org/10.15239/j.brcacadje.2017.06.01.ja02

\section{INTRODUCTION AND LITERATURE REVIEW}

Satisfaction and motivation are key indicators of student engagement and success in online learning. Not surprisingly, many pedagogical studies focus on these two areas. An important component of online learning effectiveness is faculty satisfaction and motivation to teach online. A pillar of online teaching quality proposed by the Online Learning Consortium (OLC) is "faculty (being) pleased with teaching online, citing appreciation and happiness" (Moore, 2005, 2). Despite advancing technology, proliferation of personal devices that can be adapted for online learning, and institutional pressure to offer online courses, many instructors resist the transition to teaching online (Mitchell, Parlamis \& Claiborne, 2015; De Jong, 2012). While many factors contribute to 
instructors' resistance to change, it is important to understand the specific aspects of the job that influence an instructor's satisfaction and motivation to teach in an online format. Understanding how and why classroom and online instructor satisfaction differ can provide insights for improvements in instructor satisfaction and delivery.

Faculty understanding of the unique challenges and opportunities presented by online teaching will likely create the conditions for a successful online course. On the other hand, faculty who are not as aware or fully vested in implementing best online teaching practices are more likely to teach poorly. Chickering and Gamson $(1987,2001)$ identified best practices as seven principles of job design that correspond to student learning and instructor satisfaction, while (Shieh et al, 2008) demonstrate the struggle of faculty to translate these best practices from the classroom to the online course. Surveys of self-efficacy in teaching (Horvitz, Beach, Anderson \& Xia, 2014) suggest that perception of student learning is the single most influential independent variable on satisfaction along with the demographics of the instructor. Repeatedly teaching online and in faculty cohorts is associated with faculty satisfaction (Moore, 2005). Each of these studies suggests future work to provide faculty members with training and support structures.

\section{Barriers to Teaching Online}

Previous research addressed barriers to teaching online. These barriers include the initial framework identified by Muilenberg (2001), which included multiple perspectives of those involved (including institutions, policy makers, users, as well as instructors). The ten factors found by Muilenberg (2001) to be most challenging for distance learning adoption were administrative structure, organizational change, technical expertise, social interaction and quality, faculty compensation and time, threat of technology, legal issues, evaluation of effectiveness, access, and studentsupport services. Lloyd, Byrne and McCoy (2012) listed four areas of faculty concern related to low online teaching satisfaction: interpersonal barriers (e.g., lack of creating interpersonal relationships with students), 


\section{The BRC Academy Journal of Education Vol. 6, No. 1}

institutional barriers (e.g., online teaching not valued for promotion and tenure), training and technology barriers (e.g., lack of support therein), and cost/benefit analysis barriers (e.g., increased workload and time commitment).

\section{Motivating Factors to Teach Online}

Shea (2007) identified specific motivators including teaching schedule flexibility, the opportunity to experiment with new pedagogy, and altruism related to providing learning access to underserved groups. A later replication of this study again found that novelty and enabling access were emergent motivators (MacKeogh \& Fox, 2008). Bollinger and Wasilik's (2009) meta-analysis of previous research categorizes potential motivators into three categories: student related, instructor related, and institutional related factors. Student-related factors identified by Bollinger and Wasilik (2009) most often refer to the instructor's desire to afford higher education to a student population that would not otherwise be able to attend due to other obligations. Instructor-related factors for motivation to teach online included the challenge of providing high-quality instruction using technology while institutional-related factors refer to the value placed on online learning by the institution. Interestingly, Ragsdale (2011) summarized previous findings on faculty motivators with an eye on providing tools for administrators dealing with resistance to adoption. These motivators allowed faculty to observe and practice prior to teaching an online course; manage realistic teaching time commitments; foster a supportive community of practice; emphasize online education the institutional benefits; define extrinsic rewards; and recognize intrinsic motivators. The promotion of intrinsic motivators is arguably the most effective strategy in engaging faculty in online pedagogy. Intrinsic motivators such as intellectual challenge, use of innovative technology, and the self-motivation required for effective online teaching have been found to be the most compelling factors to teach online (Panda \& Mishra, 2007). Notably, advantages to online instruction 
identified in these studies are the intellectual challenge for faculty and scheduling flexibility (Green, Alejandro \& Brown, 2009; Maguire, 2005).

Emerging research explores concepts of job satisfaction as it relates to the practice of online teaching. Margalina et al. (2014) used a framework of relational coordination in examining how supporting organizational structures positively reinforced perceptions of faculty satisfaction. The research that explores faculty satisfaction and motivation is tactical and prescriptive, but lacks a conceptual or theoretical foundation. This paper proposes a job analytical/design approach to understanding faculty satisfaction and motivation to teach online.

\section{Job Design MoDel}

Research has long supported the finding that sound work design influences employee performance, motivation and job satisfaction (Wageman, Hackman \& Lehman, 2005). Past research stressed characteristics of the work itself that influence work outcomes. Early research focused on scientific management and job rotation. Building on Herzberg's (1979) concepts, job enrichment is among the early constructs that emphasized the meaning of the tasks themselves (Gullickson, 2011; Hackman, Oldham, Janson, \& Purdy, 1975). Subsequent attention focused on the Core Job Characteristics model (Hackman \& Lawler, 1975; Hackman \& Oldham, 1980; Hackman \& Oldham, 1976) and the psychometric properties of the Job Diagnostic Survey (JDS) and the Job Description Inventory (Wageman, Hackman \& Lehman, 2005; Cordery \& Sevastos, 1993; Fried, 1991; Taber \& Taylor, 1990; Sims, Szilagyi, \& Keller, 1976). Research has established the job characteristics model and supported acceptable JDS psychometric properties. We therefore employ the Core Job Characteristics model in the present paper (Figure 1).

The Core Job Characteristics model (Hackman \& Lawler, 1975) states that core job characteristics lead to critical psychological states, that in turn result in favorable outcomes (e.g., performance, satisfaction, low 
absenteeism and low turnover). Skill variety refers to the faculty belief that they use their valued skills. Task Identity is the perception that work is holistic and viewed in its totality rather than an isolated small piece of the whole. Task significance is the belief that the work matters and is important. These three core dimensions result in job meaningfulness. Job autonomy is the amount of decision-making authority a person has with respect to the execution of their work. Job Autonomy leads to experienced responsibility for work outcomes. Feedback results in experienced knowledge of results and increased motivation, long believed by psychologists to be important for performance and satisfaction.

An important job characteristics model implication is to imbed the core characteristics into work so that employees perceive that work is meaningful, employees take responsibility for their success and failures, and performance improves based on feedback from the work itself. These critical psychological states of perceived meaningfulness, responsibility and knowledge of results result in increased performance, motivation and job satisfaction. The last element of the model is that employees vary with respect to their need for the job characteristics (growth need strength). Hackman and Lawler (1975) contain comprehensive accounts of the model. The Core Job Characteristics model serves as a theoretical foundation to compare online and traditional classroom instruction. The two instructional delivery modes overlap in some respects (e.g., subject matter, cases, and assigned readings). However, the two delivery modes may differentially influence faculty motivation and satisfaction if one exercises more of the core job characteristics than the other.

Measuring student engagement and learning can be challenging, especially when there is limited face-to-face contact. Yet, there are aspects of online teaching that give the faculty member an advantage in an online course. The student must read the text, module content, or other supporting material prior to completing an assignment or discussion. In the classroom, students may not feel the same sense of urgency to engage proactively with the material since a faculty member is physically 
in the classroom to provide verbal guidance, transmit information, and provide immediate feedback to the student. In this respect, online learning is a good option for students who are self-regulated and independent (Abrahamson, 1998). Similarly, we often see that students with full-time jobs and personal obligations choose online courses for the flexibility they offer (Allen \& Seaman, 2008, Mitchell, Parlamis \& Claiborne, 2015). These "non-traditional" students may be more motivated to deeply understand content and excel because the concepts are relevant to their occupation and will enable advancement through the acquisition of knowledge, skills, or degrees (Bye, Pushkar \& Conway, 2007). Therefore, the challenge with online instruction is not necessarily a lack of student engagement and learning. Instead, the challenge lies in our ability as instructors to find fulfillment along the core job characteristics. Fulfillment of the three psychological states of job characteristic theory are required to keep instructors motivated and performing well (Oldham \& Hackman, 2005; Oldham, Hackman, Smith, \& Hitt 2005).

If we consider that motivation, and ultimately performance, in online instruction is impacted by the three psychological states, we are able to utilize the five job characteristics to evaluate and redesign the work to improve both satisfaction and performance. Preliminary analysis of the Core Job Characteristics dimensions help us understand how elements of online instruction influence each psychological state for the online instructor and provide implications for future research.

\section{Skill Variety}

Depending on individual approaches to instruction, faculty may find there to be more skill variety in one instructional delivery mode versus another. When we breakdown the actual activities being performed in the classroom and online, there are many similarities. The verbal presentation of material is often the most often cited difference between instructional delivery modes (Simonson, Smaldino, Albright, \& Zvacek, 2014). The control of the classroom associated with the face-to-face lecture and facilitation is one of the most difficult aspects for the instructor to 
forego when moving to online instruction (Palloff \& Pratt, 2013). Yet, there are opportunities for video lectures and synchronous/live sessions in online courses. Depending on faculty practice in online courses, there may be less facilitation and direct feedback to students due to scalability, or class size. Finally, faculty may employ in-class activities or simulations to emphasize key learning objectives in the classroom. Facilitation of active learning in an online environment may present unique challenges, but technological advances in conferencing software, simulations, and collaborative work spaces provide growing alternatives to face-to-face learning. These emerging technologies require a higher level of technical proficiency on the part of both instructors and students. The job characteristic of skill variety contributes to the psychological state of experienced meaningfulness, or the extent to which the instructor finds the work meaningful and can offer their unique skills to others.

\section{Task Identity}

Task identity in the classroom is well defined. Classrooms are physical environments in which the faculty member and student meet and interact each week. Furthermore, many faculty members received their education in a traditional, classroom environment and may feel more comfortable in a physical classroom than in a more abstract online setting (Oleson $\&$ Hora, 2014). Online instruction may not be as well defined in terms of approach, best practices, and expectations.

Another way to conceptualize Task Identity is the opportunity to directly observe the learning process, student by student. Bloom's taxonomy may be useful in this context (Bloom et al, 1956). Classroom instruction may afford greater first hand observation of students as they progress through the remembering, understanding, applying, analyzing, evaluating and creating learning domains as compared to online instruction (Halawi, Pires, \& McCarthy, 2009). As students and faculty interact increasingly in an online or blended format, the discrepancy in task identity across delivery modes may diminish. Task Identify also contributes to the instructor's psychological state of experienced meaningfulness. 


\section{Task Significance}

Faculty members may have had instructors that inspired them to teach. These relationships form over the course of a semester(s) as the faculty member and student learn more about one another. Faculty-student interaction in an online environment can be more challenging as the student and faculty member may not physically see and/or hear one another in an asynchronous environment (Kuo, Walker, Schroeder, \& Belland, 2014). As a result, the extent to which a faculty member may have an impact on a student in an online course is unclear, yet this is the third job characteristic that is required to fulfill a sense of experienced meaningfulness for the online instructor.

\section{Autonomy}

Pedagogical autonomy refers to the extent that faculty are free to choose teaching methods, materials and content. Of course, faculty also differ with respect to their preferences. For example, certain faculty members may prefer speaking and storytelling, while others may prefer the use of mixed media and technology. Traditional classrooms tend to be rigid in location and time, while learning management systems, faculty technical skill, and Information Technology (IT) restrict the range of options and autonomy afforded to faculty in the online classroom. Autonomy directly impacts the psychological state of experienced responsibility, or the degree to which the instructor feels they are both accountable and responsible for the quality of the instruction.

\section{Feedback}

Similar to Task Identity, many faculty members place value on the immediate feedback they receive from students with respect to subject matter mastery as well as their own classroom performance. Verbal and non-verbal cues available in traditional settings help faculty ascertain a wide range of student emotions, including comprehension, excitement and engagement. In an asynchronous online setting; however, students have time to construct their responses. Feedback in terms of learning is 
captured most often with written assessments and examinations. While certain students may email or speak with the faculty directly in online courses, most students may limit these direct interactions. Regardless of teaching format, faculty often collect student evaluations at the end of the course, but this is a lagging indicator of performance. The job characteristic of feedback influences the third and final psychological state, knowledge of results.

\section{FUTURe ReseARCH}

The Core Job Characteristics model has implications for improving faculty online instruction satisfaction, motivation and performance by directly influencing instructors' critical psychological states of experienced meaningfulness, experienced responsibility, and knowledge of results. Future research can explore the impact of increased skill variety, task variety and task significance on experienced instructor satisfaction and performance. For example, the impact of training and use of enhanced technology designed to increase synchronous student discussions on satisfaction and motivation can be explored.

Online techniques and technology that enables instructors to more fully observe student progression through Bloom's Taxonomy stages of learning should also be explored. Such research may help understand methods that increase online instructors' level of task identity. Instructor familiarity and increased competence using enhanced online technologies may also increase perceived job autonomy as instructors decrease their dependence on IT assistance.

\section{Conclusion}

Given increases in online course offerings, we have an opportunity and an obligation to critically evaluate the determinants of instructor satisfaction and motivation. We propose that evaluating online instruction 
using the Core Job Characteristics is a useful framework. Through the job characteristics model, we've identified differences that influence faculty member satisfaction and motivation to teach online. The Core Job Characteristics provide a framework to make recommendations for job redesign to improve faculty member satisfaction, motivation, and performance.

\section{REFERENCES}

Abrahamson, C. E. (1998). Issues in interactive communication in distance education. College Student fournal, 32, 33-42.

Allen, I. E., \& Seaman, J. (2008). Staying the Course: Online Education in the United States, 2008. Sloan Consortium. PO Box 1238, Newburyport, MA 01950.

Bloom, B. S.; Engelhart, M. D.; Furst, E. J.; Hill, W. H.; \& Krathwohl, D. R. (1956). Taxonomy of educational objectives: The classification of educational goals. Handbook I: Cognitive domain. New York: David McKay Company.

Bollinger, D. U., \& Wasilik, O. (2009). Factors influencing faculty satisfaction with online teaching and learning in higher education. Distance Education, 30(1), 103-116. doi.org/10.1080/01587910902845949.

Bye, D., Pushkar, D., \& Conway, M. (2007). Motivation, interest, and positive affect in traditional and nontraditional undergraduate students. Adult Education Quarterly, 57(2), 141-158. doi.org/10.1177/0741713606294235.

Chickering, A., \& Gamson, Z. (1987). Seven Principles for Good Practice in Undergraduate Education. AAHE Bulletin, March 1987, 3-7.

Chickering, A., \& Gamson, Z. (2001). Implementing the seven principles of good practice in undergraduate education: Technology as lever. Accounting Education News, 9-10.

Cordery, J. L., \& Sevastos, P. P. (1993). Responses to the original and revised job diagnostic survey: Gournal of Applied Psychology, 78(1), 141-143. doi.org/10.1037/0021-9010.78.1.141. 
De Jong, O. (2012). Empowering teachers for innovations: The case of online teacher learning communities. Creative Education, 3, 125-129. doi.org/10.4236/ce.2012.38B026.

Fried, Y. (1991). Meta-analytic comparison of the job diagnostic survey and job characteristics inventory as correlates of work satisfaction and performance. Journal of Applied Psychology, 76(5), 690-697. doi.org/10.1037/0021-9010.76.5.690.

Green, T., Alejandro, J., \& Brown, A. (2009). The Retention of Experienced Faculty in Online Distance Education Programs: Understanding Factors that Impact their Involvement. The International Review of Research in Open and Distributed Learning, 10(3), 1-15.

Gullickson, L. (2011). Herzberg's theory of motivation as applied to community college full-time and adjunct online faculty (Order No. 3450646). Doctoral dissertation. Available from ProQuest Education Journals. (865049594).

Hackman, R. J., Oldham, G., Janson, R., \& Purdy, K. (1975). A new strategy for job enrichment. California Management Review, 17(4), 57-71. .doi.org/10.2307/41164610.

Hackman, J. R., \& Oldham, G. R. (1980). Work redesign. Reading, MA: Addison-Wesley.

Hackman, J. R., \& Oldham, G. R. (1975). Development of the Job Diagnostic Survey. Journal of Applied Psychology, 60, 159-170. doi.org/10.1037/h0076546.

Hackman, J. R., \& Oldham, G. R. (1976). Motivation through the design of work - test of a theory. Organizational Behavior and Human Performance, 16(2), 250-266. doi.org/10.1016/0030-5073 (76)90016-7.

Halawi, L. A., Pires, S., \& McCarthy, R. V. (2009). An evaluation of Elearning on the basis of bloom's taxonomy: An exploratory study. Journal of Education for Business, 84(6), 374-380. doi.org/10.3200/ JOEB.84.6.374-380.

Herzberg, F. (1979). Motivation and innovation: Who are workers serving? California Management Review, 22(2), 60. doi.org/10.2307/41165321. 
Horvitz, B., Beach, A., Anderson, M., \& Xia, J. (2014). Examination of Faculty Self-efficacy Related to Online Teaching. Innovative Higher Education, 40(4), 305-316. doi.org/10.1007/s10755-014-9316-1.

Kuo, Y. C., Walker, A. E., Schroder, K. E., \& Belland, B. R. (2014). Interaction, Internet self-efficacy, and self-regulated learning as predictors of student satisfaction in online education courses. The Internet and Higher Education, 20, 35-50.

Lloyd, S. A., Byrne, M. M., \& McCoy, T. S. (2012). Faculty-perceived barriers of online education. Journal of Online Learning and Teaching, 8(1), 1-12.

MacKeogh, K. \& Fox, S. (2008). Opening access to higher education to all? What motivates academic staff in traditional universities to adopt elearning? In: Fifth European Distance \& eLearning Network Research Workshop, 2008, 20-22 October 2008, Paris, France.

Maguire, L. (2005). Literature Review - Faculty Participation in Online Distance Education: Barriers and Motivators. Online fournal of Distance Learning Administration (8)1-12.

Margalina, V., Carmen de Pablos Heredero, Jose Luis Montes Botella, Antón Rafael García Martinez, (2014). The Role of Relational Coordination in Final Teacher Satisfaction in e learning. Procedia Technology (16), 365-375.

Mitchell, L. D., Parlamis, J. D., \& Claiborne, S. A. (2015). Overcoming faculty avoidance of online education: From resistance to support to active participation. fournal of Management Education, 39(3), 350-371. doi.org/10.1177/1052562914547964.

Moore, J.C. (2005). A synthesis of Sloan-C effective practices. Fournal of Asynchronous Learning Networks, 9(3), 5-73.

Muilenburg, L.Y. \& Berge, Z.L. (2001). Barriers to distance education: A factor-analytic study. The American fournal of Distance Education. 15(2): 7-22. doi.org/10.1080/08923640109527081.

Oldham, G. R., Hackman, J. R., Smith, K. G., \& Hitt, M. A. (2005). How job characteristics theory happened. The Oxford handbook of management theory: The process of theorydevelopment. 
54 The BRC Academy Journal of Education Vol. 6, No. 1

Oleson, A., \& Hora, M. T. (2014). Teaching the way they were taught? Revisiting the sources teaching knowledge and the role of prior experience in shaping faculty teaching

practices. Higher Education, 68(1), 29-45.

Palloff, R. M., \& Pratt, K. (2013). Lessons from the virtual classroom: The realities of online teaching. John Wiley \& Sons.

Panda, S., \& Mishra, S. (2007). E Learning in a Mega Open University: Faculty attitude, barriers and motivators. Educational Media International, (44) 4, 323-338S. doi.org/10.1080/09523980701680854.

Ragsdale, S. (2011). The Complex and Motivating Factors that Affect Faculty Adoption of Teaching Online. Fournal of Applied Learning Technology, (1) 1, 6-9.

Shea, P. (2007). "Bridges and Barriers to Teaching Online College Courses: A Study of Experienced Online Faculty in Thirtysix Colleges." Journal of Asynchronous Learning Networks, 11(2), 73-128.

Shieh, R. S., Gummer, E., \& Niess, M. (2008). The Quality of a Web-Based Course: Perspectives of the Instructor and the Students. Techtrends: Linking Research \& Practice to Improve Learning, 52(6), 61-68. doi.org/10.1007/s11528-008-0220-3.

Simonson, M., Smaldino, S., Albright, M., \& Zvacek, S. (2014). Teaching and learning at a distance. Information Age Pub.

Sims, H. P., Szilagyi, A. D., \& Keller, R. T. (1976). The measurement of job characteristics. Academy of Management fournal, 19(2), 195-212. doi.org/10.2307/255772 PMid:1029346.

Taber, T. D., \& Taylor, E. (1990). A review and evaluation of the psychometric properties of the job diagnostic survey. Personnel Psychology, 43(3), 467-500. doi.org/10.1111/j.1744-6570.1990.tb02393.x.

Wageman, R., Hackman, J. R., \& Lehman, E. (2005). Team diagnostic survey: Development of an instrument. The fournal of Applied Behavioral Science, 41(4), 373-398. doi.org/10.1177/0021886305281984. 


\section{Citation Information}

Friedman, Barry A., Sarah Bonzo, and Gregory F. Ketcham. "Instructor Satisfaction and Motivation in Online Teaching Environments: A Job Design Framework." The BRC Academy fournal of Education 6, no. 1 (2017): 41-56. http://dx.doi.org/10.15239/j.brcacadje.2017.06.01.ja02

\section{Appendix}

Figure 1. Core job characteristics model.

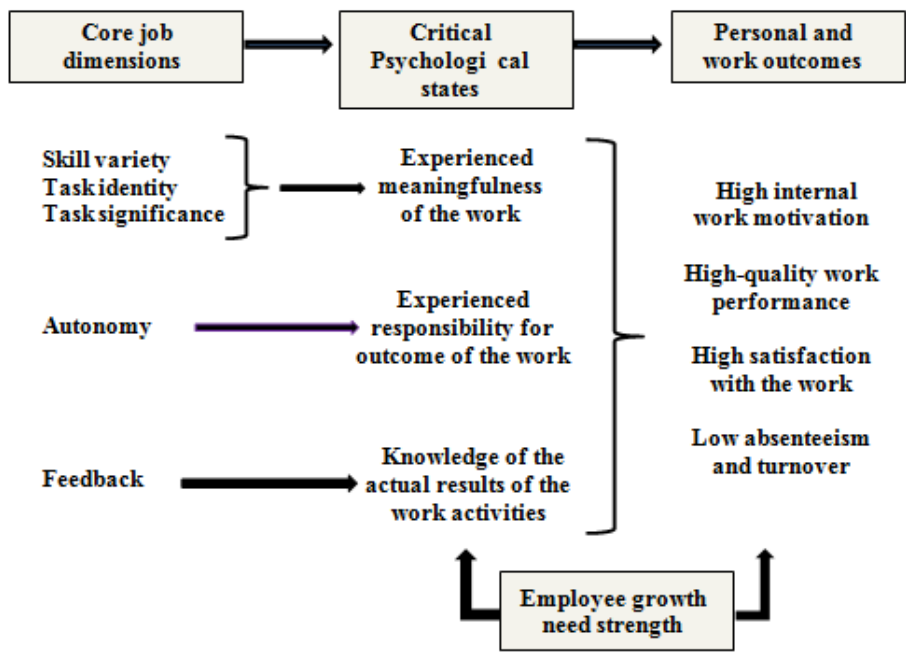

Source: from Hackman, J. R., \& Oldham, G. R. (1975). Development of the Job Diagnostic Survey. Fournal of Applied Psychology, 60, 159-170. http:// dx.doi.org/10.1037/h0076546. 


\section{The BRC Academy Journal of Education Vol. 6, No. 1}

Figure 2. Core job characteristics and online instruction.

\begin{tabular}{|c|c|c|}
\hline $\begin{array}{l}\text { Core Job } \\
\text { Dimension }\end{array}$ & Aspects of Instruction & Online Teaching Implications \\
\hline Skill Variety & $\begin{array}{l}\text { - Presentation skills } \\
\text { - Facilitation of cases/simulations } \\
\text { - Facilitation of student discussions } \\
\text { - Processing skills } \\
\text { - Group dynamics skills } \\
\text { - Interpersonal skills } \\
\text { - Class management skills } \\
\text { - Assessment skills } \\
\text { - Feedback skills }\end{array}$ & $\begin{array}{l}\text { - Identify, develop and deploy online valued } \\
\text { skills. } \\
\text { - Vary online instructional methods } \\
\text { - Provide technical tools, training and } \\
\text { assistance that increase faculty ability to } \\
\text { effectively facilitate cases, discussions and } \\
\text { student interactions } \\
\text { - Provide tools that make feedback to students } \\
\text { more informational and motivating }\end{array}$ \\
\hline Task Identity & $\begin{array}{l}\text { - Content expertise } \\
\text { - Student experience in delivery mode } \\
\text { - Clarity in expectations of instructor } \\
\text { - Availability of support }\end{array}$ & $\begin{array}{l}\text { Provide faculty with technology and } \\
\text { opportunities to facilitate students through } \\
\text { the learning process (Bloom, 1956). }\end{array}$ \\
\hline $\begin{array}{l}\text { Task } \\
\text { Significance }\end{array}$ & $\begin{array}{l}\text { - Student learning } \\
\text { - Student engagement with faculty } \\
\text { - Student engagement with peers }\end{array}$ & $\begin{array}{l}\text { - Increase online tools that assess the impact } \\
\text { teaching has on students }\end{array}$ \\
\hline Autonomy & $\begin{array}{l}\text { - Instructor ownership of content } \\
\text { - Flexibility in approach to instruction } \\
\text { - Flexibility in schedule }\end{array}$ & $\begin{array}{l}\text { - Provide institutional flexibility regarding } \\
\text { online teaching decisions: course content, } \\
\text { methods and techniques } \\
\text { - Provide technology and assistance to expand } \\
\text { faculty choices among online methods. } \\
\text { - Provide training to decrease instructor IT } \\
\text { dependence }\end{array}$ \\
\hline Feedback & $\begin{array}{l}\text { Student: } \\
\text { - Performance along key learning } \\
\text { objectives } \\
\text { - Interest in material } \\
\text { - Satisfaction with course throughout the } \\
\text { semester } \\
\text { - Satisfaction with course at the end of } \\
\text { the semester } \\
\text { - Satisfaction after course }\end{array}$ & $\begin{array}{l}\text { Provide opportunities and technologies that } \\
\text { personalize the feedback faculty receive from } \\
\text { students that the teaching is effective and has } \\
\text { impact }\end{array}$ \\
\hline
\end{tabular}

Source: Adapted from Hackman, R. J., Oldham, G., Janson, R., \& Purdy, K. (1975). A new strategy for job enrichment. California Management Review, 17(4), 57-71. http://dx.doi.org/10.2307/41164610. 